\title{
Reimagining Field Education in Social Work: The Promise Unveiled
}

\author{
Purnima George \\ Susan Silver \\ Susan Preston
}

\begin{abstract}
The current wave of neo-liberalism in Canada has driven our universities to retreat from their responsibilities as public institutions, accountable to their communities. In this paper we present a case study of field education in Canada and discuss the implications of the neoliberal academy on social work field education. On the basis of our experience as faculty consultants of BSW and MSW students, and coming from a school of social work that embraces an anti-oppression perspective as its guiding philosophy, we undertake a reconceptualization exercise in which we re-imagine field education. We politicize field education as a site with transformative possibilities. We describe the principles and processes that inform our reconceptualization and offer an example of how this might be realized in practice. This paper contributes towards developing new knowledge that unveils the promise of transformative change through a re-imagination of field education.
\end{abstract}

Keywords: Neo-liberalism, academy, social work, field education

The current wave of neo-liberalism has driven Canadian universities to reconsider their responsibilities as public institutions to their communities. While the mission statements of universities proclaim their social responsibility to communities through providing relevant and responsive education, in reality, this mission is being replaced with an entrepreneurial agenda. Neo-liberalism within academia is aptly described by Shore (2008) as the "transformation of the traditional liberal and enlightenment idea of the university as a place of higher learning into the modern idea of the university as corporate enterprise ... maximizing economic return and investment, and gaining competitive advantage in the global knowledge economy" (p. 282). This shift in universities' mission has profoundly affected social work education.

As neo-liberalism becomes more entrenched within universities, the mission of social work begins to shift away from engaging communities outside the academy towards meeting the new demands of neoliberalism. This trend is contrary to the stated mission of social work offered by the Canadian Association of Social Work Education (CASWE) and the Canadian Association of Social Workers (CASW). According to CASWE, the mission of social work is "to promote change and achieve equity and social justice" (CASWE, 2011). This mission obligates a commitment by schools of social work to marginalized communities, centering these communities in all aspects of social work education, including classroom teaching, field education, and research. Within this perspective, the role of social work education would be aligning with communities and working towards transformative change. This mission is critical in the current neo-liberal context where we are witnessing deepening inequalities and injustices within

Purnima George, Ph.D., is an Associate Professor, Susan Silver, Ph.D., is an Associate Professor; and Susan Preston, Ph.D., is an Associate Professor, all in the School of Social Work at Ryerson University in Toronto. 
marginalized communities. However, schools of social work have interpreted this mission in a manner that tends to fit, rather than challenge, the individualistic and corporate shifts we are experiencing in the academy (Larner, 2000). This is particularly evident in the design and delivery of field education.

For the most part, field education continues to be delivered in a very traditional manner, with critical thinking limited to the classroom at best. Instead of challenging the status quo, this traditional model actually reinforces the neo-liberal agenda (Preston, George \& Silver, In press). In preparing students for social work practice, the current model of field education primarily situates students within the context of an agency. Students in our school spend approximately 900 hours in the BSW and 450 hours in the MSW. Their practice training includes acquiring an understanding the practices and processes of their placement agency and assisting in the delivery of services to individuals and groups. Consequently in this model, the scope of practice is limited to an agency context.

This model does not center the community nor does it recognize its critical role in preparing students to promote equity and social justice within the broader societal context. With its focus on agency-based practice, this model of field education reinforces the very neo-liberalism that our mission proposes to challenge (Aronson \& Sammon, 2000; Preston, George \& Silver, In press). As Wiebe (2010) points out, "The field education experience ought to provide students with the opportunity to go beyond analysis to active engagement in social justice work" (p. 70). The current model of field education was not explicitly designed to forge alliances between schools of social work and communities, though some placement contexts might provide these experiences. Given the deepening marginalization of our communities (Fanelli \& Paulson, 2010; Mowbray, 2010; Purcell, 2009; Rose, 1996), it is timely and urgent for social workers to engage with the agenda of social justice, equity, and transformative change.

Coming from a Canadian school of social work that embraces an anti-oppression perspective as its guiding philosophy, we consider this lack of alignment of field education with the original mission of social work as a missed transformative opportunity. On the basis of our experience as faculty consultants of BSW and MSW students, we have come to visualize field education as a site with multiple possibilities, such as: the possibility for alliance building with communities; the possibility of being a critical partner in the process of social change; and last but not the least, the possibility for preparing future social workers for activism and transformative change.

We recognize that this process of reimagining field education is fraught with many tensions, particularly as academics are increasingly becoming neo-liberal subjects (Burchell, 1998; Davies \& Petersen, 2005; Olssen \& Peters, 2005). While we acknowledge the limits of reconceptualizing field education within the current neo-liberal context, we also recognize that it is imperative that we resist the neo-liberal project and not surrender ourselves to its dictates.

Much of the research on neo-liberalism focuses on academia and explores ways of disrupting managerialism in academy, not on how the academy could engage with communities (Anderson, 2008; Barnett \& Griffin, 1997; Clark, 1998; Fisher \& Rubenson, 
1998; Giroux, 2003; Kelsey, 1998; Meemeduma, 2001; Rhoades \& Slaughter, 1997; Slaughter, 1998; Slaughter \& Leslie, 1998). Similarly, the literature on field education in social work has focused on exploring ways of strengthening the conventional model of field (Andharia, 2011; Lager \& Robbins, 2004; Todd \& Schwartz, 2009, Wehbi \& Turcotte, 2007). This paper contributes towards developing new perspectives on field education that unveil the promise of transformative change. We do not wish to provide a recipe but instead, stimulate further critical thinking and dialogue.

\section{The Neo-Liberal Academy}

Neo-liberalism has turned the academy away from being a public institution and towards functioning as a capitalist enterprise (Barnett \& Griffin, 1997; Carroll \& Beaton, 2000; Clark, 1998; Fisher \& Rubenson, 1998; Giroux, 2003, 2010; Kelsey, 1998; Meemeduma, 2001; Rhoades \& Slaughter, 1997; Slaughter, 1998; Slaughter \& Leslie, 1998). This shift has transformed knowledge into a commodity just like other goods and services (Sit, 2008). As a public institution the academy's responsibility towards achieving the social good is redefined in economic terms with an assumption that such economic development will be beneficial to everyone. Thorpe (2008) understands this shift as a "crisis in the very idea of the university as an institution ... [with] the complete subordination of intellectual life to instrumental values and most brutally, to the measure of money" (p.1). Deem and Brehony (2005) see this as an ideological shift that maintains relations of power and domination by administrative hierarchies. This shift in the academy's vision is reflected in the curriculum, roles of academics, and governance of the academy.

With the shift to neo-liberalism there is an increasing expectation that the university will adapt its curriculum to meet the demands of the market, privileging research that will attract external research grants and striving towards developing demand for markets (Deem \& Brehony, 2005; Polster, 2005). Based on this focus, neo-liberalism has privileged research over teaching and service (Fairweather, 1996; Gaffikin \& Perry, 2009; Hughes, 2007). There is an increasing pressure on academics to pursue research funds by securing external grants (Deem \& Brehony, 2005; Gaffikin \& Perry, 2009; Jacobs, 2004; Newson, 1998; Polster, 2005).

These trends are accompanied by management practices that emphasize "efficiency, accountability and competition" (Aronson \& Smith, 2010, p. 531). They encourage a culture of individualism and competition between academics (Larner, 2000; Shore, 2008; Sit, 2008; Whitley, Aguiar, \& Marten, 2008) at the expense of collective well-being. Anderson, Johnson, and Miligan (1996) perceive these practices as fitting with Foucault's (1991) assertion of 'governmentality' by coupling 'individualization' and 'totalization' through a single message that there is only one 'right way' to succeed. Anderson and colleagues (1996) find that managerialist approaches to performance appraisals and reward systems in academia encourage individualism while reaffirming the totalizing message that there is only one "right way" to succeed. Zipin (2006) examines how this "governmentality" highlights institutionalized bullying and weakens the autonomy and agency of academics (p. 26). Marginson and Terry (1995) describe performance reviews as "the key parts of the education panopticon, a way to steer from a distance" (p. 9). 
These changes have constrained the creativity and leadership within faculty members in areas that are not deemed as productive or income generating (Clegg, 2008; Kezar, Lester, Carducci, Gallant, \& McGavin, 2007).

At the departmental levels, research is becoming more significant, measured annually through indicators such as research income, research activity, grant applications and success rates (Green, 2008; Larner \& Heron, 2005). To be competitive, faculty are discouraged from undertaking research that is founded on social justice perspectives, as such perspectives are likely to receive less funding (Wehbi \& Turcotte, 2007). This system rewards the entrepreneurial professors who generate research income and peerreviewed journal publications (Anderson, 2002; Anderson, 2008; Baldwin \& Krotseng, 1985). Although universities still include teaching and service as valued attributes, tenure and promotion committees are increasingly devaluing service and teaching and focusing on research outcomes (Boyer, 1996).

The consequence of this trend is the retreat of the academy from its engagement with communities. In withdrawing its attention away from the issues facing communities, the academy is continuing to relinquish its responsibility as a public institution (Mollis, 2006; Pusser, 2002; Thorpe, 2008). Boyer (1996) proposes a "scholarship of engagement" which implicates institutions of higher learning as partners in pursuing "our most pressing social, civic and ethical problems" (p. 19). Boyer maintains that engaged "campuses would be viewed by both students and professors not only as isolated islands, but staging grounds for actions ...” (p. 20). Slocum and Rhoads (2009) also challenge the withdrawal of the academy from its communities and instead, provide a democratic emancipatory vision of the university as a "socially transformative agent concerned with active engagement in social problems (as opposed to claiming a position of neutrality) and addresses democratically negotiated social good ...” (p.88).

We concur with Boyer (1996) and Slocum and Rhoads (2009), in that, schools of social work can play a significant role in re-establishing the social mission of our universities. Based on their unique advantage of being connected to communities through field education, schools of social work could act as a bridge that reconstructs reciprocal relations between the academy and the community.

Schools of social work have been particularly affected by the neo-liberal transformation of the academy. The essence of social work education is based on partnerships between the academy and communities. As faculty are compelled to focus inward on scholarship productivity (Kilpatrick, Turner, \& Holland, 1994), they become less focussed outside the academy and with communities. Given this inward focus, faculty manage these neoliberal tensions by restaging critical perspectives in the classroom and less in the field. We find ourselves becoming complacent with classroom activism, and as such, our activist intentions remain rhetorical rather than enacted.

\section{Problematizing our Current Model of Field Education}

In this section, we problematize certain aspects of our current model of field education. Consistent with many other schools of social work in Canada, our current model is primarily agency-based and focussed on service delivery. This model has 
remained strikingly constant over time, with only incremental changes since its inception. While designed during the expansion of the welfare state, the model prepares students for service delivery within a social rights and institutional approach to social welfare (Hick, 2004; Rice \& Prince, 2003; Westhues, 2006). In the current neo-liberal context, there is a steady withdrawal of the state, a move to a residual model of social welfare and a retrenchment of funding for social services (Burke \& Silver, 2012). The current model of field education lacks the capacity to respond to this erosion of services. While some schools may have tinkered with the practicum in terms of its goals and objectives, these changes have not interrogated the philosophical and theoretical foundations of the current model and their contributions to neoliberalism. The current model depoliticizes field education, providing symptomatic relief within a neoliberal construction of social welfare. Rarely does the current model engage in activities that challenge the causes and processes of marginalization and oppression. Hence, this perspective continues to shape the delivery of field education.

As an agency-based model, field education primarily occurs in agencies that provide individualized and group-based services. Within a context of neoliberalism, scholars have critiqued this model as it privileges service delivery at the expense of broader understanding of social issues and their impact (Aronson \& Sammon, 2000). The inherent limitation of this model is that the training students receive is limited to addressing solely the symptomatic manifestations and not the root causes of marginalization. Students have limited engagement with communities and with the day to day experiences of oppression and exclusion.

Within an agency-based model, it is assumed that problems can be effectively addressed through programs and services (Baines, 2004). Hence, programs and services within this model become an end in themselves, and not as a means towards social transformation (Fisher \& Shragge, 2000; Leighninger, 1999; Mullaly, 2001; Razack, 2002). This approach to field education tends to decontextualize and depoliticize practice, ignoring historical relations of power and processes of marginalization. This is in sharp contrast to the critical social work perspective students get exposed to in the classroom. Within this context, field education prepares students for depoliticized practice.

A further problematic with the current field education model is the individualized approach to supervision. In many ways this dyadic relationship mirrors the practitionerservice user relationship. Too often, supervision in this context becomes 'expert' centered, privileging the knowledge and experience of the 'trained' practitioner / supervisor over that of others. This is in contrast with our classroom curriculum in which we challenge the assumptions of truth that are represented by notions of expertise.

The divide between theory and practice becomes even more concerning when we see distinct differences between theory in classrooms and practice in field. In particular, we note an activist focus in the classroom, drawing on new ways of thinking about structures, power, and people, without shifts in the field that support such approaches to practice. Practice, as illustrated through field education, too often remains individualfocussed, providing service to ameliorate personal needs rather than exposing and challenging the social forces that create and sustain such disparity and need. While this 
model prepares students to engage in agency-based social work, the experience it offers is limited especially when the context of practice is under siege (Aronson \& Sammon, 2000). Rossiter (2001) as well as Wehbi and Turcotte (2007) highlight the tension between educating employable practitioners and educating activist social workers. Therefore, while the classroom curriculum remains critical of the changing context of practice, field education does not reflect the same responsiveness.

At best this approach to field education is a missed opportunity for schools of social work to engage with communities and enact our transformative vision. At worst, this model unleashes vast numbers of students into agencies, ultimately practicing in ways that reinforce the status quo. Given these concerns, it is imperative that schools of social work address the question of how to politicize field education. How do we structure field education to contribute towards a transformative agenda?

We need to work differently with agencies and communities, so that we can respond to the issues that are the most concerning for these communities. The issues of significance to marginalized communities do not necessarily conform to agency mandates and services - rendering these invisible. Field provides schools with the opportunity to be responsive to communities by realigning ourselves with agencies and communities. In this section, we propose a model of field education that centers social transformation and repositions the field as a site of resistance.

\section{Re-imagining Field Education}

We begin our attempt at re-imagining field education by repositioning it as the center of social work education. We recognize that for social work practice to be transformative within the current neo-liberal context there is a need to reimagine field education with the rest of the curriculum. Our re-imagination exercise re-examines the core principles of social work. These principles, described below, have informed our reconceptualization of field education, and we suggest they would continue as the foundation of this reimagined approach to field education.

\section{(1) Historical and Current Relations of Power and Processes of Marginalization}

Challenges of marginalized groups and communities must be understood through the lens of historical and current relations of power (Fook, 2002; Smith, 1999). In the process of service delivery, issues must be seen in the larger context, and this must inform all aspects of the student's interaction with the community (Fook, 2002).

\section{(2) Contextual Understanding}

The re-imagined field education will be based on an understanding that learning always occurs within a context. Drawing on the concept of contextual practice (Fook, 2002) we believe that to prepare students for contextual practice even field education has to be geared towards exposing students to the nature of context and its consequent effects on communities. The current insular form of agency-based practice does not provide enough exposure to the neo-liberal context and its impact on communities. Such an exposure will prepare students to consider the complexity of social work practice in 
current times and develop their abilities to "work with whole contexts, rather than simply a number of disparate players within a context” (Fook, 2002, p. 143). This understanding of context would also enhance the possibility for applying the knowledge learned in the classroom.

Within this principle of contextual understanding is the importance of relevance field education needs to be relevant to the emerging challenges of our communities in the current times. As such, field education will go beyond the model of delivering existing services to understanding the context specific challenges and engaging with communities in developing relevant responses towards those challenges (Healy, 2000). It is only by being rooted in the context of the community, through a strong bonding with the community, that you can know what the issues are (Finn \& Jacobson, 2008; Kahn, 1991) and therefore guide the field placement experience to respond to those issues.

\section{(3) Reciprocality}

The re-imagined field education will be based on the principle of reciprocality, in that our vision reflects a shift away from the transactional nature of reciprocity and towards a community-university process of building synergies for social transformation. More specifically, we believe in the primacy of engagement, relationality, and accountability to our communities, as these are critical foundational components required for building synergy (Potts \& Brown, 2005; Shragge, 2003). This principle implies the co-creation and exchange of critical knowledge, as students and faculty stand in solidarity with communities as a partner in the process of transformation. This would allow schools of social work and their universities to fulfill their mandate as public institutions committed to the issues and needs facing communities.

\section{(4) Reflexivity}

We list reflexivity as the final principle as this principle critically draws on the other principles as its tools or dimensions for uncovering new ways of knowing. We consider reflexivity as a process of deep reflection, one through which we locate and implicate ourselves in relation to our perspectives, actions, relations, and structures that are produced and reproduced. We deepen our reflexivity by incorporating and implicating ourselves through a historical and contextual understanding of the operations of power and oppression. Such a reflexive process contributes to uncovering power relations and structures of domination. New ways of understanding that emerge from this process will build the capacity for reciprocity that is authentic and transformative (D'Cruz, Gillingham \& Melendez, 2007; Fook, 2002; Heron, 2005; Kondrat, 1999).

\section{Our Vision}

Our vision represents a significant shift from current approaches to field education. We suggest a new approach to the field placement experience, one that centers communities through the delivery of field education. This shift would change the process 
and roles of all partners in field education: students, faculty, field instructors, and community members.

\section{(1) Community-based Field Education}

The foundational change we envisage is a deliberate shift away from an agencybased model to a community-based approach. In doing so, we are not abandoning agencies, but are instead seeking ways to broaden activist intentionality beyond a single agency. In this way, we recognize the vulnerabilities that agencies face as entities dependent on the state - which delineates their focus to service-delivery alone.

In working from a community model of field education, we bring a strategic focus to the issues that communities are confronting. By not solely focusing on the agency and its service provision, this approach can open up the space for a number of agencies to come together to align with communities (Rubin \& Rubin, 2001; Shragge, 2003). Given the funding restrictions on advocacy (Aronson \& Sammon, 2000; Cox, 2001), in this model, it is the community that is engaged in advocacy, with support from agencies and the academy. Thus, with a community model, we are broadening the scope of field education, from service delivery in a single setting to also include social action in a community with a community of agencies (Gamble \& Weil, 2010; Rothman, 2007). The purpose and intentions of the field placement become driven by, for, and within the community, rather than through an agency-specific mandate. The change in focus for field education, from the localized mandate of an agency to the broader goals and intentions of a community, will require changes in the delivery of field education itself its processes and roles - and that change begins with the school's field education office.

\section{(2) Field Education Office - from Placement Model to Hub Model}

In our re-imagining exercise, we consider a corresponding revisioning of the role and processes of field education. The current processes of field education, driven by managerialism, require performance indicators that are often limited to numbers, particularly the number of students placed. Consequently, the primary function of the field education office is recruiting placements and matching students. Neo-liberal management systems, supporting this primary function, are reflected by the importance given to legal contracts and placement agreements with agencies, an emphasis on learning contracts, systems of assessments and reporting assessments and other documentation pertaining to the placement agency (Ife, 1997). As an example of our concerns, we object to the current system of legal contracts with placement agencies as these legal contracts are increasingly replacing the strong university-community relations of the past. These contracts, in fact, challenge the image of a university as a public institution, further distancing the university from its communities and agencies. While some of these tools, such as learning plans and student evaluations, would inevitably continue within the new approach, they will be seen as a part of an overall community model.

Based on these considerations we envision the field education office to play a significantly different role (see Figure 1). We imagine that the Field Education Office 
might become a "hub" - a space similar to the notion of a "public sphere" (Giroux, 2010; Habermas, 1989) for community members and academics to meet and deliberate on contemporary social issues and explore ways of taking action on these issues. In this space, historical and current relations of power can be interrogated, as the contexts in which issues are discussed reflect broader and critical dimensions. Further, opportunities for reciprocality are made possible, as these inform the intentions of the deliberations. We further envisage that field opportunities for students would emerge from these deliberations.

Figure 1. Field Education Hub and Community Action Connectedness

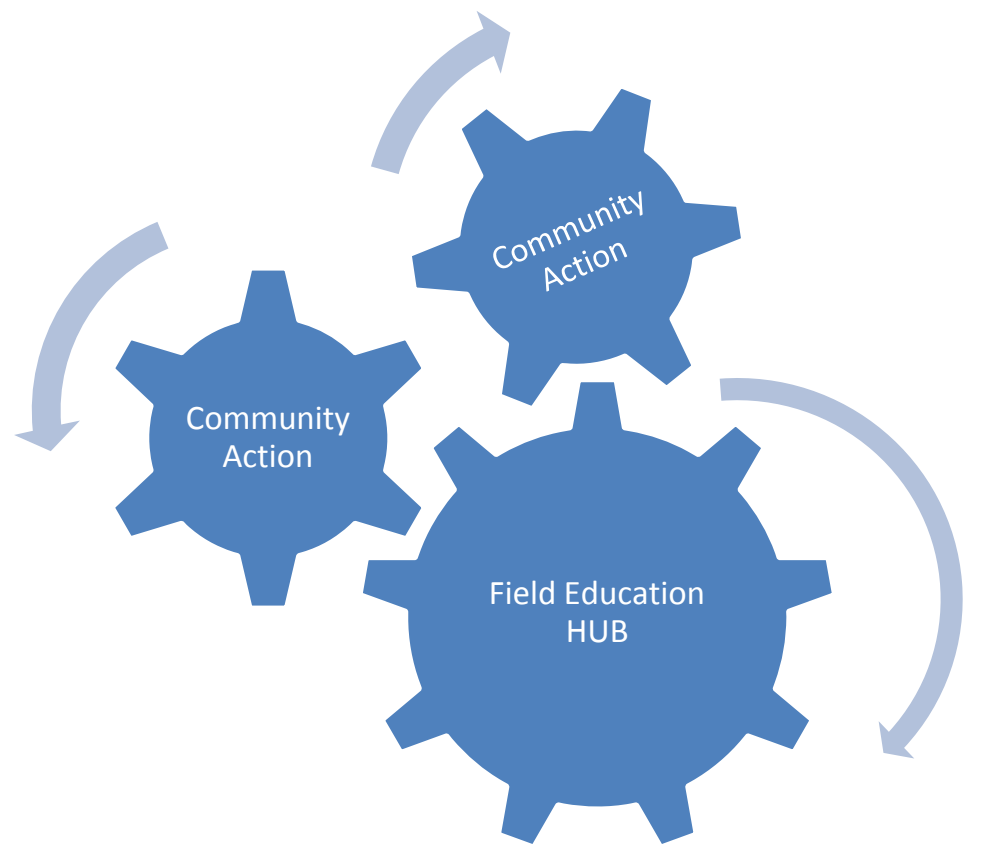

The Field Education Office would facilitate dialogues with communities, agencies and social movements. These dialogues could result in the identification of priority issues and the development of alliances based on these issues. This process could lead to a shift from agency-based matching to issue-based matching with schools of social work cocreating students' learning opportunities in dialogue with communities. As described earlier, such a collective effort opens up the possibility of going beyond individual and program-based approaches to broader and more critical ways of identifying and addressing priority issues.

To support this shift in field education, the role of the faculty consultant and the field instructor would need to incorporate a stronger liaison function. Faculty consultants and field instructors have always been strategically positioned to connect the academy with communities. In our vision, we intentionally politicize this liaison role, moving beyond bridging to mobilization and social transformation. We see their roles as critical to 
facilitating the dialogues, identification of priority issues, formation of issue-based alliances and in the development of mobilization strategies. Faculty consultants and field instructors would be able to plan student practicums that emerge from these collective processes and mobilization strategies. Performance indicators of field education and student supervision would thus be tied to these collective processes and outcomes.

Faculty consultants, field instructors, and students would have the opportunities to participate in transformative processes along with agencies and communities. This dynamic process would expand the capacity for critical reflexivity, as participants are able to interrogate and implicate themselves in relation to processes of oppression and transformation. Through this process, the academy can play an integral role as a "socially transformative agent concerned with active engagement in social problems" (Slocum \& Rhoades, 2009). In the section that follows, we provide a brief example of how our vision might be enacted in relation to the issue of food security.

\section{Field Education and Food Security - An Example}

Our example begins with the field education office organizing various dialogues with communities and agencies in relation to identifying issues of concern for communities. Through these dialogues, many issues could emerge and be prioritized for further action. For the purpose of this paper, a priority issue that could emerge would be food security among new and racialized immigrants. An alliance would then be forged with stakeholders committed to tackling this issue. Stakeholders could include members of the community, grass roots agencies, mandated agencies, and faculty. Through on-going discussions, this alliance would develop a transformative strategy and specific actions in relation to the strategy. Emanating from this strategy, faculty consultants and field instructors could then identify various sites, responsibilities, and tasks that constitute student practicums. Students from different years of the BSW and MSW programs would be matched to these practicums emanating from the issue of food security and placed in various sites implicated by the issue, such as: grass roots agencies located within a geographic community/neighbourhood; social service agencies working in that community/neighbourhood; responsible government departments; and any citizen coalitions and social movements that community members are a part of. Responsibilities generated within these sites could include: working with the geographic community and families affected by the issue; developing local initiatives at the community level to address the issue; working with food banks, schools, community health agency, local businesses in relation to the issue; developing policies or programs with government departments and political representatives; conducting research on food security; and connecting this issue with other campaigns against poverty and unemployment.

While students may be working in various sites, their efforts are coordinated by the faculty consultants and field instructors, with members of the food security alliance paying particular attention to tracking the overall progress towards transformative change. This model further provides opportunities for students to work in a team or individually and to coordinate their efforts across agencies and communities. While a student may be placed in a specific site, they will have to work with students placed in other sites, with all students contributing to the overall transformative strategy. In this 
approach, student learning is enriched, and their contributions are mobilized towards realizing the broader goal of social change. It is the confluence of student learning and an agenda of social transformation that sets this model apart from current practices. In the process, the academy and its communities are united in resisting the pervasive neoliberalism. Consequently, field education becomes a site through which collective efforts can be marshalled in the fight towards social justice and against neoliberalism.

\section{Conclusion}

While our visioning exercise has been exhilarating, the prospect of implementing this vision is daunting. Our goal is to develop a different conceptualization of field education, one which provides a new vision and a hope within the current neo-liberal context. We offer broad possibilities and processes that restructure field education from the current model to a "staging ground for actions" (Boyer, 1996, p. 20). Field education becomes a collective space for deliberating and acting on the issues most relevant to communities. Practicums thus emerge through these deliberations and, in turn, students participate and contribute to this activist agenda. Our focus on a community model is not intended as a binary that devalues the current agency model. Instead, our vision encompasses agencies and recognizes their potential contributions towards a transformative agenda through field education.

We realize the many challenges and tensions in shifting field education as suggested by our vision. We also recognize that our vision may offend as many readers as it may inspire. However, we hope that our colleagues, committed to social change, will explore ways in which they can contextualize this activist agenda within their delivery of field education.

\section{References}

Anderson, D., Johnson, R., \& Miligan, B. (1996). Performance-based funding of universities. Commissioned Report no. 51. Canberra: Australian National Board of Employment, Education, and Training, Higher Education Council.

Anderson, E. (2002). The new professoriate. Washington, DC: American Council on Education.

Anderson, G. (2008). Mapping academic resistance in the managerial university. Organization, 15(2), 251-270.

Andharia, J. (2011). Field work education in community organization: Privileging the process of political engagement. Community Development Journal, 46(SI), i96-i116. doi:10.1093/cdj/bsq045.

Aronson, J., \& Sammon, S. (2000). Practice amid social service cuts and restructuring: Working within the contradictions of "small victories". Canadian Social Work Review, 17(2), 167-187.

Aronson, J., \& Smith, K. (2010). Managing restructured social services: Expanding the social. British Journal of Social Work, 40, 530-547. 
Baines, D. (2004). Pro-market, non-market: The dual nature of organizational change in social services delivery. Critical Social Policy, 24(1), 5-29.

Baldwin, R., \& Krotseng, M. (1985). Incentives in the academy: Issues and options (New Directions for Higher Education, No. 51). San Francisco, CA: Jossey-Bass.

Barnett, R., \& Griffin, A. (Eds.). (1997). The end of knowledge in higher education. London, UK: Cassell.

Boyer, E. (1996). The scholarship of engagement. Journal of Public Service and Outreach, 1(1), 11-20.

Burchell, G. (1998). Liberal government and techniques of the self. In A. Barry, T. Osborne, \& N. Rose (Eds.), Foucault and political reason: Liberalism, neoliberalism and rationalities of government (pp.19-36). Chicago, IL: University of Chicago Press.

Burke, M., \& Silver, S. (2012). Canadian health care ... Reclaiming universal legacies. In A. Westhues \& B. Wharf (Eds.), Canadian Social Policy (5 ${ }^{\text {th }}$ ed., pp. 371-400). Waterloo, ON: Wilfred Laurier University Press.

Carroll, W., \& Beaton J. (2000). Globalization, neoliberalism and the changing face of corporate hegemony in higher education. Studies in Political Economy, 62, 71-98. Retrieved from: https://jps.library.utoronto.ca/index.php/spe/article/view/6736/3735

Canadian Association of Social Work Education (CASWE). (2011). Retrieved from http://www.caswe-acfts.ca/en/Mission_Statement_24.html

Clark, B. R. (1998). Creating entrepreneurial universities: Organizational pathways of transformation. New York, NY: Pergamon.

Clegg, P. (2008). Creativity and critical thinking in the globalized university. Innovations in Education and Teaching International, 45(3), 219-226.

Cox, E. O. (2001). Community practice issues in the $21^{\text {st }}$ century: Questions and challenges for empowerment-oriented practitioners. Journal of Community Practice, 9(1), 37-55.

Davies, B., \& Petersen, E. B. (2005). Neo-liberal discourse in the Academy: The forestalling of (collective) resistance. LATISS: Learning \& Teaching in the Social Sciences, 2(2). Retrieved from: http://www.intellectbooks.co.uk/journals/viewArticle,id=5953/

D’Cruz, H., Gillingham, P., \& Melendez, S. (2007). Reflexivity, its meanings and relations for social work: A critical review of the literature. British Journal of Social Work, 37, 73-90.

Deem, R., \& Brehony, K. J. (2005). Management as ideology: The case of 'new managerialism' in higher education. Oxford Review of Education, 31(2), 217-235.

Fairweather , J. (1996). Faculty work and the public trust: Rethinking the value of teaching and public service in American academic life. Boston, MA: Allyn \& Bacon. 
Fanelli, C., \& Paulson, J. (2010). Municipal malaise: Neoliberal urbanism and the future of our cities. Retrieved from Centre for Research on Globalization website: http://www.globalresearch.ca/index.php?context=va\&aid=19246

Finn, J. L., \& Jacobson, M. (2008). Just practice: A social justice approach to social work ( $2^{\text {nd }}$ ed.). Peosta, IA: Eddie Bowers Publishing Co.

Fisher, D., \& Rubenson, K. (1998). The changing political economy: The private and public lives of Canadian university. In J. Currie \& J. Newson (Eds.), University and globalization: Critical perspectives (pp. 77-99). Thousand Oaks, CA: Sage Publications.

Fisher, R., \& Shragge, E. (2000). Challenging community organizing: Facing the 21st century. Journal of Community Practice, 8(3), 1-19.

Fook, J. (2002). Social work: Critical theory and practice. Thousand Oaks, CA: Sage Publications.

Foucault, M. (1991). Governmentality. In C. Gordon, G. Burchitt, \& P. Miller (Eds.), The Foucault effect: Studies in governmentality (pp. 87-104). London, UK: Harvester Wheatsheaf.

Gaffikin, F., \& Perry, D. C. (2009) Discourses and strategic visions: The U.S. research university as an institutional manifestation of neoliberalism in a global era. American Educational Research Journal, 46(1), 115-130.

Gamble, D. N., \& Weil, M. (2010). Community practice skills: Local to global perspectives. New York, NY: Columbia University Press.

Giroux, H. (2003). Selling out higher education policy. Futures in Education, 1(1), 179200.

Giroux, H. (2010). Bare pedagogy and the scurge of neoliberalism: Rethinking higher education as a democratic public sphere. The Educational Forum, 74(3), 184-196.

Green, R. G. (2008). Tenure and promotion decisions: The relative importance of teaching, scholarship, and service. Journal of Social Work Education, 44(2), 117128.

Habermas, J. (1989 English translation). The structural transformation of the public sphere: An inquiry into a category of bourgeois society. Cambridge, MA: The MIT Press.

Healy, K. (2000). Social work practices: Contemporary perspectives on change. London, UK: Sage.

Heron, B. (2005). Self-reflection in critical social work practice: Subjectivity and the possibilities of resistance. Reflective Practice, 6(3), 341-351.

Hick, S. (2004). Social welfare in Canada: Understanding income security. Toronto, ON: Thompson Educational Publishing, Inc. 
Hughes, J. C. (2007). Challenging the research teaching divide. Education Canada, 48(1), 52-72.

Ife, J. (1997). Rethinking social work: Towards critical practice. South Melbourne, Australia: Addison Wesley Longman.

Jacobs, J. (2004). Dark age ahead. New York, NY: Random House.

Kahn, S. (1991). Organizing: A guide for grassroots leaders. Silver Spring, MD: National Association of Social Workers.

Kelsey, J. (1998). Privatizing the university. Journal of Law and Society, 25(1), p. 51-70.

Kezar, A., Lester, J., Carducci, R., Gallant, T. B., \& McGavin, M. C. (2007). Where are the faculty leaders? Liberal Education, 93(4), 14-21.

Kilpatrick, A., Turner, J., \& Holland, T. (1994). Quality control in field education: Monitoring students' performance. Journal of Teaching in Social Work, 9(1/2), 107120.

Kondrat, M. E. (1999). Who is the "self" in self-aware: Professional self-awareness from a critical theory perspective. Social Service Review, 73, 451-475.

Lager, P. B., \& Robbins, V.C. (2004). Field education: Exploring the future expanding the vision. Journal of Social Work Education, 40(1), 3-11.

Larner, W. (2000). Neo-liberalism: Policy, ideology, governmentality. Studies in Political Economy, 63, 5-25.

Larner, W., \& Heron, R. L. (2005). Neo-liberalizing spaces and subjectivities: Reinventing New Zealand universities. Organization, 12(6), 843 - 860.

Leighninger, L. (1999). Social service providers and the social order. Journal of Progressive Human Services, 10(2), 73-80.

Marginson, S. \& Terry, L. (1995, July 6-12). Corporatism - Specter for tomorrow. Campus Review, 9.

Meemeduma, P. (2001). The corporate university and social work academic roles. Australian Social Work, 54(4), 3-12.

Mollis, M. (2006). Latin American identities in transition: A diagnosis of Argentine and Brazilian universities. In R. A. Rhoads \& C. A. Torres (Eds.), The university, state, and market: The political economy of globalization in the Americas (pp. 60-100). Palo Alto, CA: Stanford University Press.

Mowbray, M. (2010). What became of The Local State? Neo-liberalism, community development and local government. Community Development Journal, 4 (SI), il32il53.

Mullaly, R. P. (2001). Confronting the politics of despair: Toward the reconstruction of progressive social work in a global economy and postmodern age. Social Work Education, 20(3), 303-320. 
Newson, J. (1998). The corporate-linked university: From social project to market force. Canadian Journal of Communication, 23(1), 107- 125.

Olssen, M., \& M. Peters (2005). Neoliberalism, higher education and the knowledge economy: From the free market to knowledge capitalism. Journal of Education Policy, 20(3), 313-345.

Polster , C. (2005, March 15). Making molehills out of mountains: Understanding and responding to the corporatization of Canada's universities. Paper presented at the Okanagan University College, Kelowna, BC.

Potts, K., \& Brown, L. (2005), Becoming an anti-oppressive researcher. In L. Brown \& S. Strega (Eds.), Research as resistance (pp. 255-286). Toronto, ON: Canadian Scholars' Press.

Preston, S., George, P., \& Silver, S. (In press). Field education in social work: The need for reimagining. Critical Social Work.

Purcell, M. (2009). Resisting neoliberalization: Communicative planning or counterhegemonic movements? Planning Theory, 8(2), 140-165.

Pusser, B. (2002). Higher education, the emerging market, and the public good. In P. A. Graham \& N. G. Stacey (Eds.), The knowledge economy and postsecondary education (pp. 105-125). Washington, DC: National Academy Press.

Razack, N. (2002). Transforming the field: Critical antiracist and anti-oppressive perspectives for the human services practicum. Halifax, NS: Fernwood Publishing.

Rhoades, G., \& Slaughter, S. (1997). Academic capitalism, managed professionals, and supply-side higher education. Social Text, 51(Academic Labor), 9-38.

Rice, J. J., \& Prince, M. J. (2003). Changing politics of Canadian social policy ( ${ }^{\text {rd }}$ ed.). Toronto, ON: University of Toronto Press.

Rose, N. (1996). The death of the social? Refiguring the territory of government. Economy and Society, 25(3), 327-356.

Rossiter, A. (2001). Innocence lost and suspicion found: Do we educate for or against social work? Critical Social Work, 2(1). Retrieved from http://www1.uwindsor.ca/criticalsocialwork/2001-volume-2-no-1

Rothman, J. (2007). Multi modes of intervention at the macro level. Journal of Community Practice, 15(4), 11-40.

Rubin, H. J., \& Rubin, I. S. (2001). Community organizing and development ( $3^{\text {rd }}$ ed.). Boston, MA: Allyn and Bacon.

Shragge, E. (2003). Activism and social change: Lessons for community and local organizing. Guelph, ON: Broadview Press.

Shore, C. (2008). Audit culture and illiberal governance: Universities and the politics of accountability. Anthropological Theory, 8, 278-298. 
Sit, V. (2008). The erosion of the university as a public sphere. Education Canada, 48(4), 30-45.

Slaughter, S. (1998). National higher education policy in a global economy. In J. Currie \& J. Newson (Eds.), University and globalization: Critical perspectives (pp. 45-75). Thousand Oaks, CA: Sage Publications.

Slaughter, S., \& Leslie, G. (1998). Academic capitalism. Baltimore, MD: John Hopkins University Press.

Slocum, J., \& Rhoads, R. A. (2009). Faculty and student engagement in the Argentine grassroots rebellion: Towards a democratic and emancipatory vision of the university. Higher Education, 57, 85-105. doi 10.1007/s10734-008-9134-4.

Smith, L. T. (1999). Decolonizing methodologies: Research and Indigenous peoples. London \& New York: Zed Books Ltd.

Thorpe, C. (2008). Capitalism, audit, and the demise of the humanistic academy. Workplace: A Journal for Academic Labour, 15, 103-125.

Todd, S., \& Schwartz, K. (2009). Thinking through quality in field education: Integrating alternative and traditional learning opportunities. Social Work Education, 28(4), 380395.

Wehbi, S., \& Turcotte, P. (2007). Social work education: Neoliberalism's willing victim? Critical Social Work, 8(1). Retrieved from http://www1.uwindsor.ca/criticalsocialwork/2007-volume-8-no-1

Whitley, R., Aguiar, L. M., \& Marten, T. (2008). The neoliberal transnational university: The case of UBC Okanagan. Capital and Class, 96, 115-185.

Wiebe, M. (2010). Pushing the boundaries of the social work practicum: Rethinking sites and supervision toward radical practice. Journal of Progressive Human Services, 21, 66-82.

Westhues, A. (Ed.). (2006). Canadian social policy: Issues and perspectives ( $4^{\text {th }} \mathrm{ed}$.). Waterloo, ON: Wilfred Laurier University Press.

Zipin, L. (2006). Governing Australia's universities: The managerial strong-arming of academic agency. Social Alternatives, 25(2), 26-31.

\section{Author note:}

Address correspondence to: Dr. Purnima George, Associate Professor, School of Social Work, Ryerson University, Toronto ON M5B 2K3. Email: p3george@ryerson.ca 